\title{
Studi Kasus: Asuhan Keperawatan Jiwa Pada Tn. A Dengan Risiko Perilaku Kekerasan
}

\author{
Shintiya Putri Br Tarigan \\ shintiyaputri29@gmail.com
}

\section{BAB 1}

\section{PENDAHULUAN}

\subsection{Latar Belakang}

Gangguan jiwa berat merupakan gangguan jiwa yang ditandai oleh terganggunya kemampuan menilai realitas atau tilikan (insight) yang buruk. Gejala yang menyertai gangguan ini antara lain berupa ilusi, waham, gangguan proses pikir, kemampuan berpikir, serta tingkah laku aneh, misalnya agresivitas atau katatonik. Gangguan jiwa berat dikenal dengan sebutan psikosis dan salah satu contoh psikosis adalah skizofrenia (Putri, Mella, \& Fitriani, 2018). Skizofrenia merupakan sekelompok reaksi psikotik yang memengaruhi berbagai area fungsi individu, termasuk berpikir, berkomunikasi, menerima, Menginterpretasi kan realitas, merasakan dan menunjukkan emosi. Skizofrenia merupakan gangguan kejiwaan dan kondisi medis yang mempengaruhi fungsi otak manusia, mempengaruhi fungsi normal kognitif, mempengaruhi emosional dan tingkah laku (Pardede, Siregar \& Hulu, 2020).

Privalensi skizofrenia di Indonesia berdasarkan Kemenkes (2019) berada di urutan pertama yaitu, Provinsi Bali 11,1\% dan nomor dua disusul oleh Provinsi Di Yogyakarta 10,4\%, NTB 9,6\%, Provinsi Sumatera Barat 9,1\%, Provinsi Sulawesi Selatan 8,8\%, Provinsi Aceh 8,7\%, Provinsi Jawa Tengah $8,7 \%$, Provinsi Sulawesi Tengah 8,2\%, Provinsi Sumatera Selatan 8\%, Provinsi Kalimantan Barat 7,9\%. Sedangkan Provinsi Sumatera Utara berada pada posisi ke 21 dengan privalensi $6,3 \%$. 
Skizofrenia menimbulkan distorsi pikiran, distorsi persepsi, emosi, dan tingkah laku sehingga pasien dengan skizofrenia memiliki risiko lebih tinggi berperilaku agresif dimana perubahan perilaku secara dramatis terjadi dalam beberapa hari atau minggu. Pasien skizofrenia sering dikaitkan dengan perilaku yang dapat membahayakan diri sendiri maupun orang lain ataupun berisiko juga dengan lingkungan sekitarnya, baik secara fisik, emosional, seksual, dan verbal yang disebut sebagai risiko perilaku kekerasan (Pardede, Simanjuntak \& Laia, 2020).

Perilaku kekerasan yang timbul pada skizofrenia diawali dengan adanya perasaan tidak berharga, takut dan ditolk oleh lingkungan sehingga individu akan menyingkir dari hubungan interpersonal dengan orang lain. Dampak dari klien dengan perilaku kekerasan dapat menyebabkan risiko tinggi mencederai diri, orang lain dan ingkungan. Risiko mencederai merupakan suatu tindakan yang kemungkinan dapat melukai atau membahayakan diri, orang lain dan lingkungan. Banyaknya perilaku kekerasan yang terjadi baik didunia maupun di Indonesia sendiri dikarenakan ketidakmampuan seseorang untuk mengontrol perilaku marah dengan baik. Respon terhadap marah dapat diungkapkan melalui 3 cara, yaitu : Mengungkapkan secara verbal, menekan, dan menentang. Dari ketiga cara ini, cara yang pertama adalah konstruktif sedangkan 2 cara lain adalah destruktif. Dengan melarikan diri atau menantang akan menimbulkan rasa bermusuhan, dan bila cara ini dipakai terus menerus maka kemarahan dapat berdampak pada diri sendiri atau lingkungan dan akan tampak sebagai depresi psiomatik atau agresif atau ngamuk (Aziz, 2018).

Survei awal pada pembuatan asuhan keperawatan pada skizofrenia ini dilakukan di Yayasan Pemenang Jiwa Sumatera dengan jumlah klien 70 orang tetapi yang menjadi subjek di dalam pembuatan asuhan keperawatan ini berjumlah 1 orang dengan klien risiko perilaku kekerasan dengan inisial nama Tn. A. Penyebabnya Tn. A di jadikan sebagai subjek dikarenakan klien belum bisa mengatasi emosinya selain meminum obat. Maka tujuan asuhan 
keperawatan yang akan di lakukan ialah untuk mengajarkan standar pelaksanaan risiko perilaku kekerasan/perilaku kekerasan pada saat Tn. A untuk mengontrol kemarahan dan emosinya.

\subsection{Rumusan Masalah}

Berdasarkan masalah yang telah di paparkan pada latar belakang maka rumusan masalah dalam askep ini yaitu Asuhan Keperawatan Risiko Perilaku Kekerasan Tn. A di Yasasan Pemenang Jiwa Sumatera.

\subsection{Tujuan}

\subsubsection{Tujuan Umum}

Mahasiswa mampu memberikan asuhan keperawatan secara holistik dan komprehensif kepada Tn. A dengan gangguan risiko perilaku kekerasan di Yayasan Pemenang Jiwa Sumatera.

\subsubsection{Tujuan Khusus}

a. Mahasiswa mampu memahami pengertian, tanda dan gejala, etiologi, penatalaksanaan medis dan keperawatan risiko perilaku kekerasan.

b. Mahasiswa mampu melakukan pengkajian pada Tn. A dengan gangguan risiko perilaku kekerasan.

c. Mahasiswa mampu melakukan menegakkan diagnosa pada Tn. A dengan gangguan risiko perilaku kekerasan.

d. Mahasiswa mampu melakukan menetapkan perencanaan pada Tn. A dengan gangguan risiko perilaku kekerasan.

e. Mahasiswa mampu melakukan implementasi pada Tn. A dengan gangguan risiko perilaku kekerasan.

f. Mahasiswa mampu melakukan evaluasi pada Tn. A dengan gangguan risiko perilaku kekerasan.

g. Mahasiswa mampu mendokumentasikan asuhan keperawatan yang diberikan pada Tn. A dengan gangguan risiko perilaku kekerasan. 


\subsection{Manfaat Penulisan}

1. Responden

Diharapkan tindakan yang telah di ajakarkan dapat di terapkan secara mandiri untuk mengontrol emosi dan untuk mendukung kelangsungan kesehatan klien.

2. Yayasan Pemenang Jiwa Sumatera.

Diharapkan dapat menjadi acuan dalam menanganin atau dalam memberikan pelayanan kepada klien dengan gangguan jiwa dengan perilaku kekerasan di Yayasan Pemenang Jiwa Sumatera. 


\section{BAB 2 \\ TINJAUAN TEORITIS}

\subsection{Konsep Risiko Perilaku Kekerasan}

\subsubsection{Defenisi}

Perilaku kekerasan adalah hasil dari marah yang ekstrim (kemarahan) atau ketakutan (panik) sebagai respon terhadap perasaan terancam, baik berupa ancaman serangan fisik atau konsep diri. Perilaku kekerasan adalah salah satu respon marah yang diekspresikan dengan melakukan ancaman, mencederai orang lain, dan atau merusak lingkungan . Perasaan terancam ini dapat berasal dari stresor eksternal (penyerangan fisik, kehilangan orang berarti dan kritikan dari orang lain) dan internal (perasaan gagal di tempat kerja, perasaan tidak mendapatkan kasih sayang dan ketakutan penyakit fisik) (Pardede, 2020).

Perilaku kekerasan adalah suatu bentuk perilaku yang bertujuan untuk melukai seseorang secara fisik maupun psikologis. Berdasarkan definisi ini maka perilaku kekerasan dapat dilakukan secara verbal, diarahkan pada diri sendiri, orang lain, dan lingkungan. Perilaku kekerasan dapat terjadi dalam dua bentuk, yaitu saat sedang berlangsung perilaku kekerasan atau riwayat perilaku kekerasan (Aprini \& Prsetya, 2018).

Perilaku kekerasan adalah suatu keadaan dimana seseorang melakukan tindakan yang dapat membahayakan secara fisik, baik kepada diri sendiri maupun orang lain. Sering juga disebut gaduh gelisah atau dimana seseorang marah berespon terhadap suatu stressor dengan gerakkan motorik yang tidak terkontrol (Arisandy \& Juniarti, 2020). 
Perilaku kekerasan adalah perilaku individu yang dapat membahayakan orang, diri sendiri baik secara fisik, emosional, dan atau sexualitas. Perilaku kekerasan merupakan salah satu respon maladaftif dari marah. Marah merupakan perasaan jengkel yang timbul sebagai respon terhadap kecemasan/kebutuhan yang tidak terpenuhi yang dirasakan sebagai ancaman. Perasaan marah normal bagi individu namun prilaku yang dimanifestasikan oleh perasaan marah dapat berfluktuasi sepanjang rentang adaptif dan maladaptif. Apabila perasaan marah diekspresikan dengan perilaku agresif dan menentang, biasanya dilakukan individu karena ia merasa kuat. Cara demikian dapat menimbulkan kemarahan yang berkepanjangan dan dapat menimbulkan tingkah laku yang destruktif dan tidak dapat dikendalikan (Prasetya, 2018).

\subsubsection{Etiologi}

Penyebab dari perilaku kekerasan yaitu seperti kelemahan fisik (penyakit fisik), keputusasaan, ketidakberdayaan, dan kurang percaya diri. Untuk faktor penyebab dari perilaku kekerasan yang lain seperti situasi lingkungan yang terbiasa dengan kebisingan, padat, interaksi sosial yang proaktif, kritikan yang mengarah pada penghinaan, dan kehilangan orang yang di cintai (pekerjaan). Marah merupakan perasaan jengkel yang timbul sebagai respons terhadap kecemasan (kebutuhan yang tidak terpenuhi) yang dirasakan sebagai ancaman (Putri, Mella, \& Fitriani, 2018).

Ada beberapa faktor yang mempengaruhi risiko perilaku kekerasan adalah sebagai berikut :

1. Faktor Predisposisi

1) Faktor Biologis

Hal yang dikaji pada faktor biologis meliputi adanya faktor herediter yaitu adanya anggotakeluarga yang sering memperlihatkan atau melakukan perilaku kekerasan, adanya 
anggota keluarga yang mengalami gangguan jiwa, adanya riwayat penyakit atau trauma kepala, dan riwayat penggunaan NAPZA (narkoti, psikotropika dan zat aditif lainnya) (Nurhalimah, 2016).

2) Faktor psikologis

Beberapa faktor psikologis yang mempengaruhi risiko perilaku kekerasan menurut Kandar (2019) adalah sebagai berikut :

a. Kehilangan Kehilangan adalah suatu keadaan dimana seseorang merasa kekurangan atas ketiadaan sesuatu yang tadinya ada. Kehilangan disebabkan oleh berbagai macam yaitu kehilangan orang yang dicintai, barang maupun pekerjaan. Rasa kehilangan akan menyebabkan seseorang merasa cemas hingga mengalami kecemasan yang berlebihan itulah yang akan menyebabkan seseorang mengalami gangguan kejiwaan.

b. Kepribadian Kepribadian adalah organisasi-organisasi dinamis sistemsistem psikofisik dalam individu yang turut menentukan cara-caranya yang unik/khas dalam menyesuaikan diri dengan lingkungannya. kepribadian adalah sesuatu yang menentukan perilaku dalam ketetapan situasi dan kesadaran jiwa. faktor yang mendukung terjadinya risiko perilaku kekerasan yaitu kepribadian tertutup.

3) Faktor Sosiokultural

Teori lingkungan sosial (social environment theory) menyatakan bahwa lingkungan sosial sangat mempengaruhi sikap individu dalam mengekspresikan marah.Norma budaya dapat mendukung individu untuk berespon asertif atau agresif.Perilaku kekerasan dapat dipelajari secara langsung melalui proses sosialisasi (social learning theory) (Nurhalimah, 2016).

4) Faktor sosial budaya 
Beberapa faktro sosial budaya yang mempengaruhi risiko perilaku kekerasan menurut Wulansari \& Sholihah (2021) adalah sebagai berikut :

a. Pekerjaan Faktor status sosioekonomi yang rendah menjadi penyumbang terbesar adanya gangguan jiwa dan menyebabkan perilaku agresif dibandingkan dengan pada seseorang yang memiliki tingkat perekonomian tinggi. Seseorang yang tidak memiliki pekerjaan mempengaruhi kejadian perilaku kekerasan, masalah status sosioekonomi yang rendah berdampak pada status kesehatan jiwa seseorang dan berpotensi menyebabkan gangguan jiwa dan menyebabkna perilaku agresif atau risiko perilaku kekerasan.

b. Pernikahan Penderita risiko perilaku kekerasan yang dirawat dengan gangguan jiwa memiliki riwayat status perkawinan hampir setengahnya belum menikah atau bercerai. Tidak terpenuhinya atau kegagalan dalam memenuhi tugas perkembangan pada masa perkawinan merupakan stresor bagi individu. Rasa malu dan marah dapat menimbulkan frustasi bagi penderita sehingga mengakibatkan penderita cenderung mengalami perilaku maladaptive.

2. Faktor Presitipasi

Ketika seseorang merasa terancam terkadang tidak menyadari sama sekali apa yang menjadi sumber kemarahannya. Tetapi secara umum, seseorang akan mengerluarkan respon marah apabila merasa dirinya terancam. Faktor presipitasi bersumber dari klien, lingkungan, atau interaksi dengan orang lain. Faktor yang mencetuskan terjadinya perilaku kekerasan terbagi dua, yaitu (Hulu, 2021) : 
a. Klien : Kelemahan fisik, keputusasaan, ketidak berdayaan, kurang percaya diri.

b. Lingkungan : Ribut, kehilangan orang atau objek yang berharga, konflik interaksi sosial.

\subsubsection{Tanda dan Gejala}

Tanda dan gejala perilaku kekerasan adalah sebagai berikut (Pardede, 2020) :

Subjektif :
a. Mengungkapkan perasaan kesal atau marah
b. Keinginan untuk melukai diri sendiri, orang lain dan lingkungan
c. Klien suka membentak dan menyerang orang lain

\section{Objektif :}
a. Mata melotot/pandangan tajam
b. Tangan mengepal dan Rahang mengatup
c. Wajah memerah
d. Postur tubuh kaku
e. Mengancam dan Mengumpat dengan kata-kata kotor
f. Suara keras
g. Bicara kasar, ketus
h. Menyerang orang lain dan Melukai diri sendiri/orang lain
i. Merusak lingkungan
j. Amuk/agresif

Tanda dan gejala perilaku kekerasan : Muka merah dan tegang, mata melotot/ pandangan tajam, mengepalkantangan, mengatupkan rahang dengan kuat, Bicara kasar Suara tinggi, menjerit atau berteriak, mengancam secara verbal dan fisik, melempar atau memukul benda/orang lain, merusak barang atau beda, tidak mempunyai kemampuan mencegah/mengontrol perilaku kekerasan (Malfasari, et all, 2020). 


\subsubsection{Rentang Respon}

Perilaku atau respon kemarahan dapat berkembang dalam rentang adaptif sampai mnaladaptif. Rentang respon marah dimana amuk (perilaku kekerasan) dan agresif berada pada rentang maladaptif, seperti pada gambar berikut (Azis, 2018) :

Adaptif

Maladaptif

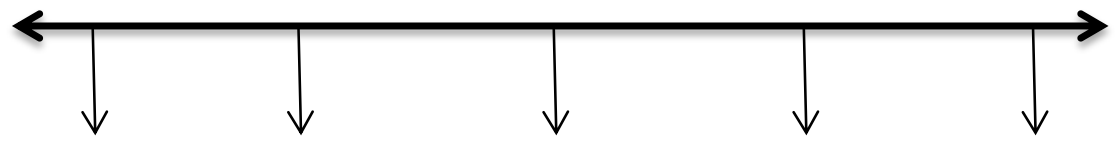

Asertif Frustasi Pasif Agresif Amuk/PK

Keterangan :

1. Asertif, merupakan ungkapan rasa tidak setuju atau kemarahan yang dinyatakan atau diungkapkan tanpa menyakiti orang lain sehingga akan memberikan kelegaan dan tidak menimbulkan masalah. Asertif merupakan bentuk perilaku untuk menyampaikan perasaan diri dengan kepastian dan memperhatikan komunikasi yang menunjukkan respek pada orang lain.

2. Frustasi, adalah respon yang terjadi akibat gagal mencapai tujuan yang tidak realistis atau hambatan dalam pencapaian tujuan.

3. Pasif, merupakan kelanjutan dari frustasi dalam keadaan ini individu tidak menemukan alternatif lain penyelesaain masalah, sehingga terlihat pasif dan tidak mampu mengungkapkan perasaannya.

4. Agresif, adalah perilaku yang menyertai marah dan merupakan dorongan untuk bertindak destruktif tapi masih terkontrol. Perilaku yang tampak berupa muka masam, menuntut, dan bicara kasar.

5. Amuk (perilaku kekerasan), yaitu perasaan marah dan bermusuhan yang kuat disertai kehilangan kontrol diri, sehingga individu dapat merusak diri sendiri, orang lain dan lingkungan. 


\subsubsection{Mekanisme Koping}

Mekanisme koping adalah cara yang digunakan individu dalam menyelesaikan masalah, mengatasi perubahan yang terjadi dan situasi yang mengancam baik secara kognitif maupun perilaku. Mekanisme koping yang umum digunakan adalah mekanisme pertahanan ego (Dwi \& Arum, 2018), seperti :

1) Displacement

Melepaskan perasaan tertekannya bermusuhan pada objek yang begitu seperti pada mulanya yang membangkitkan emosi.

2) Proyeksi

Menyalahkan orang lain mengenai keinginan yang tidak baik.

3) Depresi

Menekan perasaan orang lain yang menyakitkan atau konflik ingatan dari kesadaran yang cenderung memperluas mekanisme ego lainnya.

4) Reaksi formasi

Pembentukan sikap kesadaan dan pola perilaku yang berlawanan dengan apa yang benaar-benar dilakukan dengan orang lain.

\subsubsection{Penatalaksanaan}

Tindakan yang dilakukan perawat dalam mengurangi risiko perilaku kekerasan menurut (Sujarwo \& Livana, 2019) salah satunya adalah dengan menggunakan strategi pelaksanaan (SP). SP merupakan pendekatan yang bersifat membina hubungan saling percaya antara klien dengan perawat, dan dampak apabila tidak diberikan SP akan membahayakan diri sendiri maupun lingkungannya. Strategi pelaksanaan (SP) yang dilakukan oleh klien dengan perilaku kekerasan adalah diskusi mengenai cara mengontrol perilaku kekerasan secara fisik, obat, verbal, dan spiritual. Mengontrol perilaku kekerasan secara fisik dapat dilakukan dengan cara nafas dalam, dan pukul bantal atau kasur. Mengontrol secara verbal yaitu dengan cara menolak dengan baik, meminta dengan baik, dan mengungkapkan 
dengan baik. Mengontrol perilaku kekerasan secara spiritual dengan cara shalat dan berdoa. Serta mengontrol perilaku kekerasan dengan minum obat secara teraturdengan prinsip lima benar (benar klien, benar nama obat, benar cara minum obat, benar waktu minum obat, dan benar dosis obat).

Terapi yang diberikan untuk mengatasi klien skizofrenia dengan risiko perilaku kekerasan biasanya terapi generalis keperawatan jiwa tetapi masih belum sempurna dalam menangani klien maka perlulah terapi spesialis keperawatan untuk mempercepat kesembuhan klienseperti Behaviour Therapy yang dapat mengubah perilaku maladaptif ke adaptif (Pardede, Siregar, \& Hulu, 2020). Penatalaksanaan klien dengan risiko perilaku kekerasan juga banyak dikaji keakuratannya. Dari mulai memotivasi, terapi TAK (Terapi Aktivitas Kelompok), konsumsi obat, dan pemberian perhatian lebih dari pihak keluarga (Untari \& Kartina, 2021)

Penatalaksanaan atau penanganan perilaku kekerasan sangat diperlukan dan dapat dilakukan dengan tiga cara, yaitu program pencegahan, antisipasi dan pengekangan. Relaksasi progresif merupakan bagian dari program antisipasi. Teknik relaksasi progresif adalah memusatkan perhatian pada suatu aktifitas otot, dengan mengidentifikasi otot yang tegang kemudian menurunkan ketegangan dengan melakukan teknik relaksasi untuk mendapatkan perasaan relaks (Suryanti \& Ariani, 2018). 


\subsection{Konsep Asuhan Keperawatan}

\subsubsection{Pengkajian Keperawatan}

Pengkajian adalah pemikiran tahap awal dari proses keperawatan yang bertujuan untuk mengumpulkan informasi atau data tentang klien, agar dapat mengidentifikasi, mengenali masalah - masalah. Kebutuhan kesehatan dan keperawatan klien baik fisik, mental, sosial dan lingkungan. Dalam pengkajian teori hal-hal yang dikaji terdiri dari data umum yang berupa identitas klien, keluhan utama, riwayat penyakit, pengkajian fisik, dan pemeriksaan diagnostik. Berupa pengumpulan data umum, keluhan utama, riwayat penyakit, riwayat kesehatan psikososial, riwayat spiritual, pengkajian fisik, dan pemeriksaan diagnostik sesuai dengan teori (Arisandy \& Juniarti, 2020).

Pengkajian dilakukan dengan cara wawancara dan observasi pada klien dan keluarga. Tanda dan gejala risiko perilaku kekerasan dapat ditemukan dengan wawancara (Utari, 2021)

\section{Identitas}

Nama, umur, jenis kelamin, No MR, tanggal masuk RS, tanggal pengkajian.

\section{Alasan masuk}

Biasanya klien masuk dengan alasan sering mengamuk tanpa sebab, memukul, membanting, mengancam, menyerang orang lain, melukai diri sendiri, mengganggu lingkungan, bersifat kasa dan pernah mengalami gangguan jiwa dimasa lalu kambuh karena tidak mau minum obat secara teratur.

\section{Faktor predisposisi}
a. Gangguan jiwa dimasa lalu
b. Pengobatan sebelumnya
c. Trauma
d. Herediter
e. Pengalaman masa lalu yang tidak menyenangkan 


\section{Fisik}
a. Ukur dan observasi tanda-tanda vital
b. Ukur tinggi badan dan berat badan
c. Verbal (mengancam, mengupat kata-kata kotor, berbicara kasar dan ketus)

\section{Psikososial}
a. Genogram
b. Konsep diri Citra tubuh

\section{Hubungan sosial}
a. Orang yang berarti
b. Peran serta dalam kegiatan kelompok
c. Hambatan dalam berhubungan dengan orang lain/tingkat keterlibatan klien dalam hubungan masyarakat.

\section{Spiritual}
a. Nilai dan keyakinan
b. Kegiatan ibadah.

\section{Status mental}
a. Penampilan
b. Pembicaraan
c. Aktivitas motorik
d. Alam perasaan
e. Efek
f. Interaksi selama wawancara
g. Persepsi
h. Isi Pikir
i. Tingkat kesadaran
j. Memori
k. Kemampuan penilaian

\section{Masalah psikologis dan lingkungan}

Biasanya klien merasa ditolak dan mengalami masalah interaksi dengan lingkungan 


\subsubsection{Diagnosa Keperawatan}

Diagnosis keperawatan adalah langkah kedua dari proses keperawatan yang menggambarkan penilaian klinis tentang respon individu, keluarga, kelompok maupun masyarakat terhadap masalah klien yang nyata serta penyebabnya dapat dipecahkan atau diubah melalui tindakan. Pada diagnosa keperawatan secara teori penulis mendapatkan 8 diagnosa yaitu, risiko tinggi mencederai orang lain, Perilaku kekerasan, Gangguan harga diri kronis, Isolasi sosial, Perubahan persepsi sensori halusinasi, Koping individu tidak efektif, infektif proses terapi, berduka disfungsional (Arisandy \& Juniarti, 2020).

Menurut Utari (2021) diagnosa keperawatan pada klien denga risiko perilaku kekerasan adalah :

a) Data subjektif : klien mengatakan jengkel dengan orang lain, mengupkankan rasa permusuhan yang mengancam, klien merasa tidak nyaman, klien merasa tidak berdaya, ingin berkelahi, dendam.

b) Data objektif : suara keras, tangan mengepal, wajah memerah dan tegang, pandnagan tajam, mengatupkan rahang dengan kuat, mengepalkan tangan, bicara kasar, suara nada tinggi.

\subsubsection{Intervensi Keperawatan}

Intervensi pada klien dengan risiko perilaku kekerasan dapat dilakukan dengan pemberian teknik mengontrol perilaku kekerasan dengan pemberian SP I cara fisik yaitu relaksasi tarik nafas dalam serta penyaluran energi, SP II dengan pemberian obat, SP III verbal atau social, SP IV spiritual. Intervensi tersebut dilakukan kepada klien lalu klien diberikan jadwal kegiatan sehari dalam upaya mengevaluasi kemampuan klien mengontrol perilaku kekerasan klien (Hasannah, 2019). 


\subsubsection{Implementasi Keperawatan}

Implementasi dilakukan sesuai intervensi keperawatan pada klien dengan perilaku kekerasan dengan melihat kemampuan kognitif, afektif dan psikomotor klien. Tehnik yang perlu diperhatikan adalah strategi komunikasi, yang harus dilakukan yaitu : bersikap tenang, bicara lambat, bicara tidak dengan cara menghakimi, bicara netral dengan cara yang kongkrit, tunjukkan respek pada klien, hindari intensitas kontak mata langsung, demonstrasikan cara mengontrol situasi tanpa kesan berlebihan, fasilitasi pembicaraaan klien, dengarkan klien, jangan terburu-buru menginterpretasikan, jangan buat janji yang tidak dapat perawat sejati. Lingkungan: menyediakan berbagai aktivitas. Tindakan perilaku : membuat kontrak dengan klien mengenai perilaku yang dapat diterima (Bengi, 2021).

\subsubsection{Evaluasi Keperawatan}

Menurut Arisandy \& Juniarti (2020) evaluasi yang dilakukan perawat pada klien dengan perilaku kekerasan adalah sebagai berikut :

1) Klien mampu atau tidak melakukan strategi pelaksanaan 1 yaitu cara mengontrol marah secara fisik : tarik nafas dalam dan pukul bantal, yang mana diawali dengan membantu klien untuk mengungkapkan perasaannya serta mendiskusikan tentang penyebab marah klien dan melatih cara fisik : tarik nafas dalam dan pukul bantal.

2) Klien mampu atau tidak melakukan strategi pelaksanaan 2 yaitu cara mengontrol marah dengan cara: minum obat secara teratur.

3) Klien mampu atau tidak melakukan strategi pelaksanaan 3 yaitu mengajarkan tehknik mengontrol marah secara verbal yaitu meminta dengan baik dan menolak dengan baik lalu di masukkan kedalam jadwal aktifitas harian.

4) Klien mampu atau tidak melakukan strategi pelaksanaan 4 yaitu mengontrol perilaku kekerasan dengan cara spiritual yaitu mengaji dan berdoa dimasukkan kedalam jadwal kegiatan harian. 


\section{BAB 3 \\ TINJAUAN KASUS}

\subsection{Identitas Klien}

$\begin{array}{ll}\text { Nama } & : \text { Tn. A } \\ \text { Jenis Kelamin } & : \text { Laki-laki } \\ \text { Umur } & : \text { 62 Tahun } \\ \text { Agama } & : \text { Kriten Protestan } \\ \text { Status } & : \text { Tidak Menikah } \\ \text { Tanggal Pengkajian } & : \text { Kamis, 04 Maret 2021 } \\ \text { Informent } & : \text { Klien }\end{array}$

\subsection{Alasan Masuk}

Klien mengatakan dulu dia sering marah-marah, jika ada yang mengganggunya dia langsung memukul orang yang mengganggunya tersebut.

\subsection{Faktor Predisposisi}

Sebelum klien masuk ke Yayasan Pemenang Jiwa, klien pernah masuk ke rumah sakit jiwa. Setelah keluar dari rumah sakit jiwa, klien dibawa pulang kerumah oleh keluarganya. Tetapi setelah dibawa pulang oleh keluarga, klien sering berkelahi dengan tetangga dan teman-temannya. Sehingga keluarganya memasun Tn. A disebelah rumahnya. Setelah beberapa saat dipasung, ada keluarga yang kasihan kepada Tn. A yang dipasung oleh kelurganya, keluarga yang merasa kasihan kepada Tn. A membawa Tn. A ke Yayasan Pemenang Jiwa. Dan Tn. A sudah di Pemenang Jiwa selama 7 Tahun hingga saat ini. Dan mendengar dari penjaga Yayasan, Tn. A masih sering marah-marah dan juga memukul orang yang mengganggunya.

Masalah Keperawatan : Risiko Perilaku Kekerasan 


\subsection{Fisik}

Klien mengatakan tidak memiliki keluhan fisik saat dilakukannya pengkajian, dan hasil dari pemeriksaan tanda-tanda vital adalah :
TD : $120 / 80 \mathrm{mmHg}$
$\mathrm{RR}: 20 \mathrm{x} / \mathrm{i}$
TB : $165 \mathrm{~cm}$
HR : 80x/I
$\mathrm{S}: 36,5^{0} \mathrm{C}$
$\mathrm{BB}: 65 \mathrm{Kg}$

\subsection{Psikososial}

\subsubsection{Genogram}

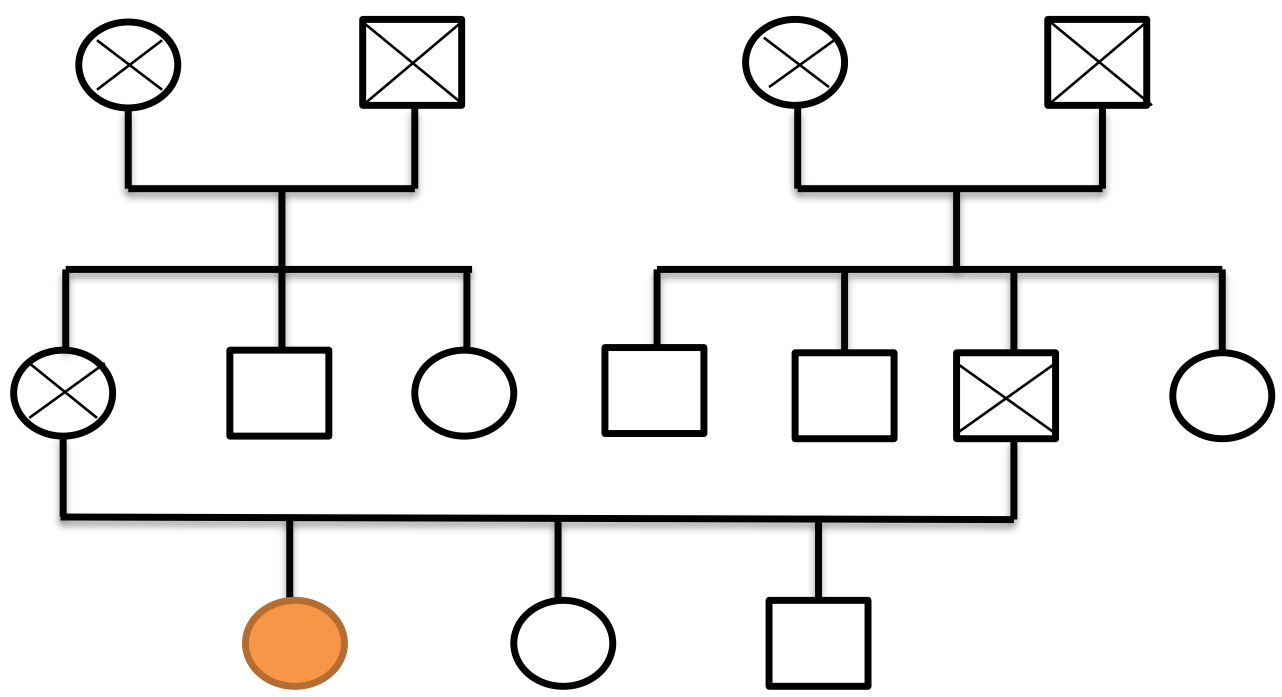

\section{Penjelasan :}

Klien 3 bersaudara, klien merupakan anak pertama dan memiliki 1 orang adik laku-laki dan 1 orang adik perempuan. Kedua orangtua klien sudah meninggal.

\section{Keterangan :}
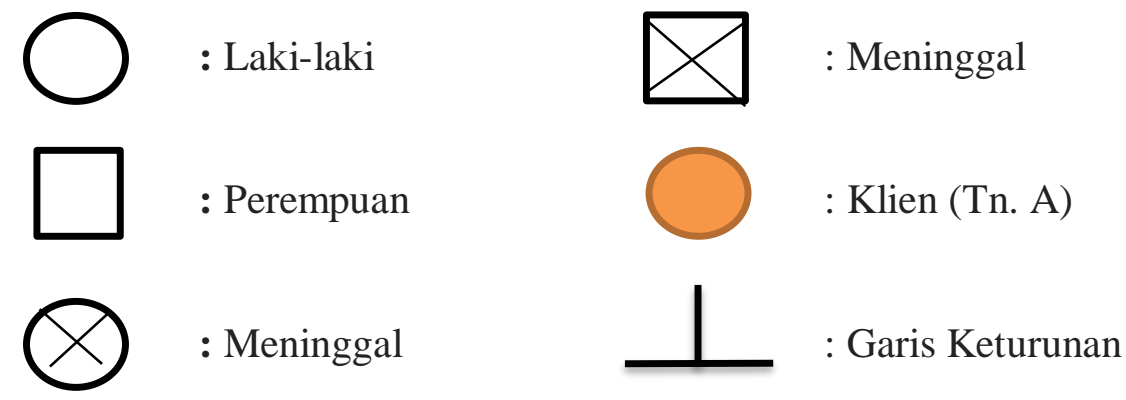


\subsubsection{Konsep Diri}

a) Gambaran diri :

Tidak ada kecacatan

b) Identitas :

Klien anak pertama dari 3 bersaudara, klien memiliki 1 adik laki-laki dan 1 adik perempuan.

c) Peran

Klien berperan sebagai anak dan masih lajang, sebelumnya klien tinggal bersama keluarganya

d) Ideal diri

Klien mengatakan nbahwa dia menyadari sakitnya dan ingin cepat sembuh

e) Harga diri :

Klien mengatakan merasa malu dengan keadaan penyakitnya saat ini, klien ingin pulang tapi klien tidak tahu mau pulang kemana

\subsubsection{Hubungan Sosial}

Klien mengganggap bahwa keluarganya adalah orang yang sangat berarti dalam hidupnya terutama orang tuanya meskipun mereka sudah meninggal. Klien tidak mengikuti kegiatan di kelompok/masyarakat seperti beribadah bersama di dalam Yayasan. Klien mengatakan mempunyai sedikit hambatan dalam berhubungan dengan orang lain karena klien sulit bergaul dan klien suka menyendiri selama tinggal di yayasan.

\subsubsection{Spiritual}

a. Nilai dan Keyakinan :

Klien beragama kristen protestan dan yakin dengan agamanya

b. Kegiatan Ibadah

Klien selalu mengikuti kegiatan sesuai jadwal selama tinggal di Yayasan Pemenang Jiwa 


\subsubsection{Status Mental}

a. Penampilan

Penampian klien bersih dan berpakaian rapi

b. Pembicaraan

Klien menjawab pertanyaan perawat dengan suara pelan namun masih mudah dipahami

c. Aktivitas Motorik

Klien terlihat sedikit gelisah

d. Alam perasaan

Klien tidak mampu mengekspresikan perasaannya sesui dengan kondisinya saat emosi

e. Afek

Afek labil, klien merespon saat dipanggil

Masalah Keperawatan : Risiko Perilaku Kekerasan

f. Interaksi selama wawancara

Klien kooperatif, ada kontak mata pada lawan bicara

g. Persepsi

Klien mengatakan sekali-sekali mendengar suara yang membuatnya marah sehingga ingin memukul orang yang ada didekatnya

Masalah Keperawatan : Gangguan Persepsi Sensori : Halusinasi

h. Proses Pikir

Klien mampu berbicara dengan baik dan klien juga mampu menjawab dengan baik

i. Isi Pikir

Klien tidak mengalami gangguan isi pikir dan klien dapat mengontrol isi pikirnya

j. Tingkat Kesadaran

Klien tidak mengalami gangguan orientasi, klien mengenali waktu, orang dan tempat. 
k. Memori

Klien tidak mampu menceritakan kejadian-kejadian dimasa lalunya

1. Tingkat Konsentrasi Berhitung

Klien mampu berkonsentrasi dalam perhitungan

m. Kemampuan penilaian

Klien dapat membedakan hal yang baik dan yang buruk.

n. Daya tilik diri

Klien tidak mengingkari penyakit yang diderita, klien sadar bahwa dia sedang mengalamu gangguan jiwa, klien mengetahui bahwa dia sering marah

Masalah Keperawatan : Harga Diri Rendah

\subsection{Mekanisme Koping}

Klien mengalami mekanisme koping adaptif yaitu klien dapat berbicara baik dengan orang lain dan berkooperatif. Dan jika dia marah atau emosi dia langsung memukul orang yang membuatnya emosi.

\subsection{Masalah Psikososial dan Lingkungan}

Klien megatakan dukungan psikososial dan lingkungan di yayasan sangat baik.

\subsection{Pengetahuan Kurang Tentang Gangguan Jiwa}

Klien mengatakan bahwa ia mengetahui kalau dirinya itu sedang menglalami gangguan jiwa.

\subsection{Aspek Medik}

Diagnosa Medis : Diagnosa medis : Skizofrenia Paranoid

Terapi medis yang diberikan :

a. Risperidon (RSP) tablet $2 \mathrm{mg} 2 \times 1$.

b. Clozapine $1 \times 1$ 
3.10 Analisa Data

\begin{tabular}{|c|c|c|}
\hline No & Analisa Data & $\begin{array}{c}\text { Masalah } \\
\text { Keperawatam }\end{array}$ \\
\hline 1. & $\begin{array}{l}\text { Ds: } \\
\text { Klien mengatakan bahwa alasan } \\
\text { saudaranya mengantarnya ke Yayasan } \\
\text { Pemenang Jiwa karena dulunya dia sempat } \\
\text { dipasung oleh adiknya karena sering } \\
\text { bertengkar dan memukul teman-temannya } \\
\text { yang disekitar rumahnya } \\
\text { Do: } \\
\text { Pandangan mata klien tampak } \\
\text { tajam/melotot, dan klien merasa gelisah } \\
\text { jika berbicara dengan orang yang baru dia } \\
\text { kenal }\end{array}$ & $\begin{array}{ll}\text { Risiko } & \text { Perilaku } \\
\text { Kekerasan } & \end{array}$ \\
\hline 2. & $\begin{array}{l}\text { Ds : } \\
\text { Klien mengatakan sekali-sekali } \\
\text { mendengar sura yang memancing emosi } \\
\text { dan membuatnya marah sehingga bisa } \\
\text { memukul orang ada didekatnya } \\
\text { Do : } \\
\text { Klien sering berbicara sendiri dan } \\
\text { mulutnya sering komat kamit tanpa suara } \\
\text { Klien tampak senyum-senyum sendiri } \\
\text { Klien tampak gelisah }\end{array}$ & $\begin{array}{l}\text { Gangguan Persepsi } \\
\text { Sensori : Halusinasi } \\
\text { Pendengaran }\end{array}$ \\
\hline 3. & $\begin{array}{l}\text { Ds: } \\
\text { Klien mengatakan bahwa dia merasa } \\
\text { dirinya tidak berharga dan tidak berguna } \\
\text { karena mengalami gangguan jiwa } \\
\text { Do: } \\
\text { Klien tampak menyendiri, dan klien } \\
\text { tampak murung }\end{array}$ & $\begin{array}{l}\text { Gangguan Konsep } \\
\text { Diri : Harga Diri } \\
\text { Rendah }\end{array}$ \\
\hline
\end{tabular}




\subsection{Masalah Keperawatan}

a. Risiko Perilaku Kekerasan

b. Gangguan Persepsi Sensori : Halusinasi Pendengaran

c. Gangguan Konsep Diri : Harga Diri Rendah

\subsection{Pohon Masalah}

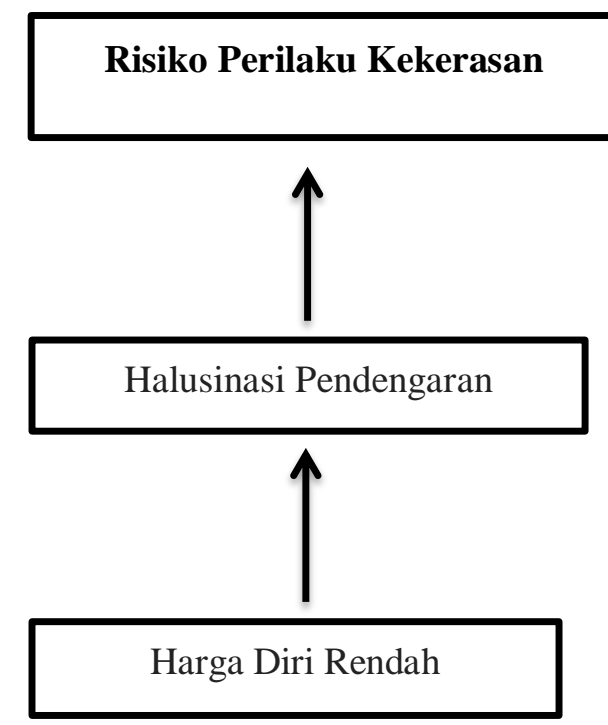

\subsection{Prioritas Diagnosa Keperawatan}

1. Risiko Perilaku Kekerasan

2. Gangguan Persepsi Sensori : Halusinasi Pendengaran 


\subsection{Intervensi Keperawatan}

\begin{tabular}{|c|c|c|c|}
\hline $\begin{array}{c}\text { Diagnosa } \\
\text { Keperawatan }\end{array}$ & Tujuan & Kriteria Hasil & Intervensi \\
\hline \multirow[t]{3}{*}{$\begin{array}{l}\text { Risiko } \\
\text { Perilaku } \\
\text { Kekerasan }\end{array}$} & $\begin{array}{l}\text { Klien dapat membina } \\
\text { hubungan saling percaya. }\end{array}$ & $\begin{array}{l}\text { Ketika di evaluasi klien mampu } \\
\text { membalas salam, tersenyum, ada } \\
\text { kontak mata serta menyediakan } \\
\text { waktu untuk kunjungan berikutnya. }\end{array}$ & $\begin{array}{l}\text { 1. Membina hubungan saling percaya dengan cara } \\
\text { menjelaskan maksud dan tujuan interaksi, } \\
\text { jelaskan tentang kontrak yang akan di buat, } \\
\text { beri rasa aman dan sikap empati. } \\
\text { 2. Diskusi bersama klien tentang perilaku } \\
\text { kekerasan, penyebab, tanda dan gejala perilaku } \\
\text { yang muncul dan akibat dari perilaku tersebut. }\end{array}$ \\
\hline & $\begin{array}{l}\text { Klien dapat } \\
\text { mengendalikan } \\
\text { mengendalikan perilaku } \\
\text { kekerasan dengan cara } \\
\text { relaksi nafas dalam dan } \\
\text { pukul bantal/kasur. }\end{array}$ & $\begin{array}{l}\text { Klien mampu menyebutan dan } \\
\text { menrekomendasikan cara } \\
\text { mengontrol perilaku kekerasan } \\
\text { dengan cara relaksasi nafas dalam } \\
\text { dan pukul bantal. }\end{array}$ & $\begin{array}{l}\text { Sp } 1 \text { : } \\
\text { Latihan Melakukan cara mengontrol amarah : } \\
\text { a) Anjurkan teknik relaksasi nafas dalam. } \\
\text { b) Pukul bantal. }\end{array}$ \\
\hline & $\begin{array}{l}\text { Klien dapat } \\
\text { mengendalikan perilaku } \\
\text { kekerasan dengan minum } \\
\text { obat secara teratur. }\end{array}$ & $\begin{array}{l}\text { Klien mampu mengendalikan } \\
\text { perilaku kekerasan dengan minum } \\
\text { obat Risperidon (RSP) dengan } \\
\text { teratur. }\end{array}$ & $\begin{array}{l}\text { Sp } 2 \text { : } \\
\text { Bantu klien mengotrol perilaku kekerasan dengan } \\
\text { minum obar secara teratur 2x1 hari. }\end{array}$ \\
\hline
\end{tabular}




\begin{tabular}{|c|c|c|c|}
\hline & $\begin{array}{l}\text { Klien paham dan mampu } \\
\text { mengendalikan risiko } \\
\text { perilaku kekerasan dengan } \\
\text { cara berbicara dengan } \\
\text { baik. }\end{array}$ & $\begin{array}{l}\text { Klien paham dan mampu } \\
\text { menyampaikan amarah dengan cara } \\
\text { berbicara dengan baik. }\end{array}$ & $\begin{array}{l}\text { Sp } 3 \text { : } \\
\text { Bantu klien mengontrol risiko perilaku kekerasan } \\
\text { dengan menganjurkan klien berbicara yang baik } \\
\text { bila sedang marah, dengan tiga cara : } \\
\text { a) Meminta sesuatu dengan baik tanpa marah. } \\
\text { b) Menolak sesuatu dengan baik. } \\
\text { c) Mengungkapkan perasaan kesal. }\end{array}$ \\
\hline & $\begin{array}{l}\text { Klien paham dan mampu } \\
\text { mengendalikan risiko } \\
\text { perilaku kekerasan dengan } \\
\text { cara mempraktikan cara } \\
\text { spritual. }\end{array}$ & $\begin{array}{l}\text { Klien paham dan mamu } \\
\text { mengendalikan risiko perilaku } \\
\text { kekerasan dengna cara beribadah } \\
\text { sesuai agama yang di anut klien }\end{array}$ & $\begin{array}{l}\text { Sp } 4 \text { : } \\
\text { Klien risiko perilaku kekerasan : Diskusikan } \\
\text { bersama klien cara mengendalikan perilaku } \\
\text { kekerasan dengan cara beribadah. }\end{array}$ \\
\hline $\begin{array}{l}\text { Gangguan } \\
\text { Persepsi } \\
\text { Sensori : } \\
\text { Halusinasi }\end{array}$ & $\begin{array}{l}\text { Klien mampu mengontrol } \\
\text { halusinasi dengan } \\
\text { menggunakan SP } \\
\text { halusinasi }\end{array}$ & $\begin{array}{l}\text { Klien mampu mengontrol halusinasi } \\
\text { menggunakan Sp } 1 \text { : } \\
\text { a. Mengidentifikasi isi, frekuensi, } \\
\quad \text { situai pencetus, dan respon }\end{array}$ & $\begin{array}{l}\text { SP 1: } \\
\text { 1. Identifikasi isi, waktu terjadi, situasi pencetus, } \\
\text { dan respon terhadap halusinasi } \\
\text { 2. Jelaskan dan Latih teknik menghardik }\end{array}$ \\
\hline
\end{tabular}




\begin{tabular}{|c|c|c|c|}
\hline Pendengaran & & $\begin{array}{l}\text { terhadap halusinasi } \\
\text { b. Klien mampu menghardik } \\
\quad \text { halusinasi } \\
\text { SP } 2 \text { : } \\
\text { Klien mampu mengontrol haluinasi } \\
\text { dengan minum obat secara teratur } \\
\text { SP } 3 \text { : } \\
\text { Klien mampu mengontrol halusinasi } \\
\text { dengan cara bercakap-cakap dengan } \\
\text { orang lain. } \\
\text { SP } 4 \text { : } \\
\text { Klien mampu mengontrol halusinasi } \\
\text { dengan cara melakukan kegiatan } \\
\text { terjadwal }\end{array}$ & $\begin{array}{l}\text { SP } 2 \text { : } \\
\text { Kontrol Halusinasi klien dengan minum obat secara } \\
\text { teratur } \\
\text { SP } 3 \text { : } \\
\text { Ajarkan cara mengontrol halusinasi dengan } \\
\text { bercakap - cakap dengan orang lain } \\
\text { SP } 4 \text { : } \\
\text { Ajarkan cara mengontrol halusinasi dengan } \\
\text { melakukan kegiatan terjadwal }\end{array}$ \\
\hline $\begin{array}{l}\text { Gangguan } \\
\text { Konsep Diri : } \\
\text { Harga Diri } \\
\text { Rendah }\end{array}$ & $\begin{array}{ll}\text { 1. } & \text { Klien dapat } \\
& \text { mengidentifikasi aspek } \\
& \text { positif dan kemampuan } \\
& \text { yang dimiliki. } \\
\text { 2. } & \text { Klien dapat menilai } \\
& \text { kemampuan yang }\end{array}$ & $\begin{array}{ll}\text { 1. } & \text { Mampu mengidentifikasi aspek } \\
& \text { positif dan kemampuan yang } \\
& \text { dimiliki. } \\
\text { 2. } & \text { Klien mampu menilai } \\
& \text { kemampuan yang dimiliki untuk } \\
& \text { dilaksanakan }\end{array}$ & $\begin{array}{l}\text { Sp 1: } \\
\text { Mengidentifikasi kemampuan dan aspek positif } \\
\text { yang dimiliki klien } \\
\text { Sp } 2 \text { : } \\
\text { a. Menilai kemampuan yang dapat digunakan }\end{array}$ \\
\hline
\end{tabular}




\begin{tabular}{|c|c|c|c|c|}
\hline & $\begin{array}{l}3 . \\
4 .\end{array}$ & $\begin{array}{l}\text { dimiliki untuk } \\
\text { dilaksanakan } \\
\text { Klien dapat } \\
\text { merencanakan kegiatan } \\
\text { sesuai dengan } \\
\text { kemampuan yang } \\
\text { dimiliki } \\
\text { Klien dapat melakukan } \\
\text { kegiatan sesuai rencana } \\
\text { yang dibuat }\end{array}$ & 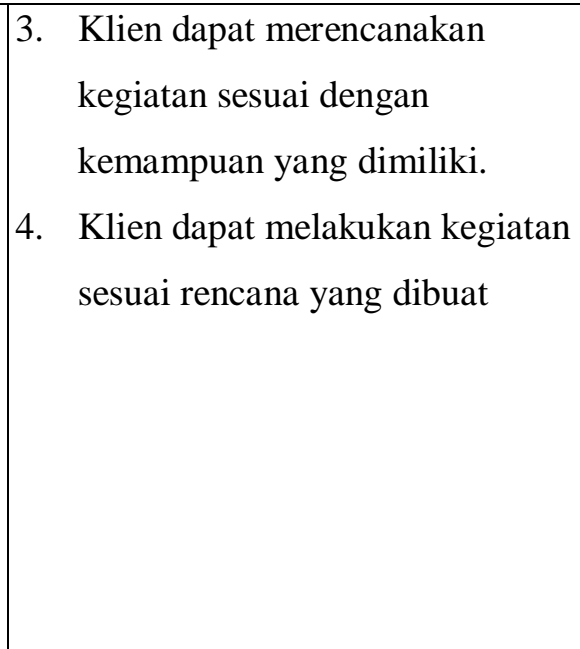 & $\begin{array}{l}\text { b. Menetapkan atau memilih kegiatan sesuai } \\
\text { kemampuan } \\
\text { c. Melatih kegiatan sesuai kemampuan yang dipilih } \\
\quad 1 \\
\text { Sp } 3 \text { : } \\
\text { Melatih kegiatan sesuai kemampuan yang dipilih } 2 \\
\text { Sp } 4 \text { : } \\
\text { Melatih kegiatan sesuai kemampuan yang dipilih } 3\end{array}$ \\
\hline
\end{tabular}




\subsection{Implementasi dan Evaluasi}

\begin{tabular}{|c|c|c|}
\hline Hari/Tgl & Implementasi & Evaluasi \\
\hline $\begin{array}{l}\text { Jumat, 05 Maret } \\
2021 \\
10.00 \text { s/d selesai }\end{array}$ & $\begin{array}{l}\text { 1. Data : } \\
\text { Tanda dan gejala : mudah marah, mudah } \\
\text { tersinggung, tatapan sinis, suka menyendiri, } \\
\text { merasa tidak dihargai } \\
\text { 2. Diagnosa Keperawatan : } \\
\text { a. Risiko Perilaku Kekerasan } \\
\text { b. Perilaku Kekerasan } \\
\text { 3indakan Keperawatan: } \\
\text { Sp1 : Risiko Perilaku Kekerasan: } \\
\text { - Mengidentifikasi penyebab risiko perilaku } \\
\text { kekerasan yaitu jika kemauan klien tidak } \\
\text { dituruti. } \\
\text { - Mengidentifikasi tanda dan gejala risiko } \\
\text { perilaku kekerasan yaitu klien marah, } \\
\text { mengamuk tanpa jelas, merusak barang- } \\
\text { barang, dan cenderung melukai orang lain. }\end{array}$ & $\begin{array}{l}\text { S : Semangat } \\
\text { O : } \\
\text { - Klien mampu melakukan latihan fisik tarik nafas } \\
\quad \text { dalam dengan mandiri } \\
\text { - Klien mampu pukul kasur bantal dengan mandiri } \\
\text { A : Risiko Perilaku kekerasan (+) } \\
\text { P : Latihan fisik: } \\
\text { - Tarik nafas dalam } 1 \mathrm{x} / \text { hari } \\
\text { - Pukul kasur bantal } 1 \mathrm{x} / \text { hari }\end{array}$ \\
\hline
\end{tabular}




\begin{tabular}{|c|c|c|}
\hline & $\begin{array}{l}\text { - Menyebutkan cara mengontrol risiko } \\
\text { perilaku kekerasan adalah dengan latihan } \\
\text { fisik : Tarik napas dalam latihan dan pukul } \\
\text { kasur bantal } \\
\text { - Membantu klien latihan tarik napas dalam } \\
\text { dan pukul kasur bantal. } \\
\text { 4. RTL : } \\
\text { Sp2 : Risiko perilaku kekerasan. } \\
\text { Mengontrol risiko perilaku kekerasan } \\
\text { dengan minum obat secara teratur. }\end{array}$ & \\
\hline $\begin{array}{lr}\text { Sabtu, 6 } & \text { Maret } \\
2021 & \\
10.00 & \text { s/d } \\
\text { selesai } & \end{array}$ & $\begin{array}{l}\text { 1. Data : } \\
\text { Tanda dan gejala : mudah marahmarah, mudah } \\
\text { tersinggung, tatapan sinis, merasa tidak } \\
\text { dihargai. } \\
\text { Kemampuan bernyanyi. } \\
\text { 2. Diagnosa Keperawatan : } \\
\text { a. Risiko perilaku kekerasan } \\
\text { b. Perilaku kekerasan }\end{array}$ & $\begin{array}{l}\text { S : } \\
\text { Bahagia dan bersemangat } \\
\mathrm{O}: \\
\text { - Klien mampu melakukan tarik nafas dalam } \\
\text { dengan mandiri } \\
\text { - Klien mampu pukul kasur bantal secara mandiri } \\
\text { - Klien meminum obat secara teratur dengan } \\
\text { bantuan perawat }\end{array}$ \\
\hline
\end{tabular}




\begin{tabular}{|c|c|c|}
\hline & $\begin{array}{l}\text { 3. Tindakan keperawatan } \\
\text { Sp2 : Risiko Perilaku Kekerasan. } \\
\text { - Mengevaluasi kemampuan klien tarik nafas } \\
\text { dalam dan pukul kasur. } \\
\text { - Memberikan informasi tentang pengguanaan } \\
\text { obat. } \\
\text {.Sp } 3 \text { Risiko Perilaku Kekerasan } \\
\text { - Mengevaluasi kemampuan klien untuk tarik } \\
\text { nafas dalam dan pukul kasur bantal } \\
\text { - Minum obat } \\
\text { - Komunikasi secara verbal : asertif/bicara } \\
\text { baik-baik } \\
\text { RTL : } \\
\text { Sp } 4 \text { Risiko Perilaku Kekerasan : } \\
\text { - Spritual : Beribadah }\end{array}$ & $\begin{array}{l}\text { - Klien mampu melakukan komunikasi secara } \\
\text { verbal : asertif/bicara baik-baik dengan motivasi } \\
\text { A : Risiko Perilaku kekerasan (+) } \\
\text { P : } \\
\text { - Latihan tarik nafas dalam } 1 \mathrm{x} / \mathrm{hari} \\
\text { - Latihan pukul kasur bantal } 1 \mathrm{x} / \mathrm{hari} \\
\text { - Berobat } \\
\text { - Klien melakukan komunikasi secara verbal : } \\
\text { asertif/bicara baik-baik }\end{array}$ \\
\hline $\begin{array}{lr}\text { Sabtu, } 6 & \text { Maret } \\
2021 & \\
10.00 \quad \text { s/d } \\
\text { selesai } & \end{array}$ & $\begin{array}{l}\text { 1. Data : } \\
\text { Tanda dan gejala : mudah marahmarah, mudah } \\
\text { tersinggung, tatapan sinis, merasa tidak } \\
\text { dihargai. } \\
\text { Kemampuan bernyanyi. }\end{array}$ & $\begin{array}{l}\text { S : } \\
\text { Bahagia dan bersemangat } \\
\text { O : } \\
\text { - Klien mampu melakukan tarik nafas dalam } \\
\quad \text { dengan mandiri }\end{array}$ \\
\hline
\end{tabular}




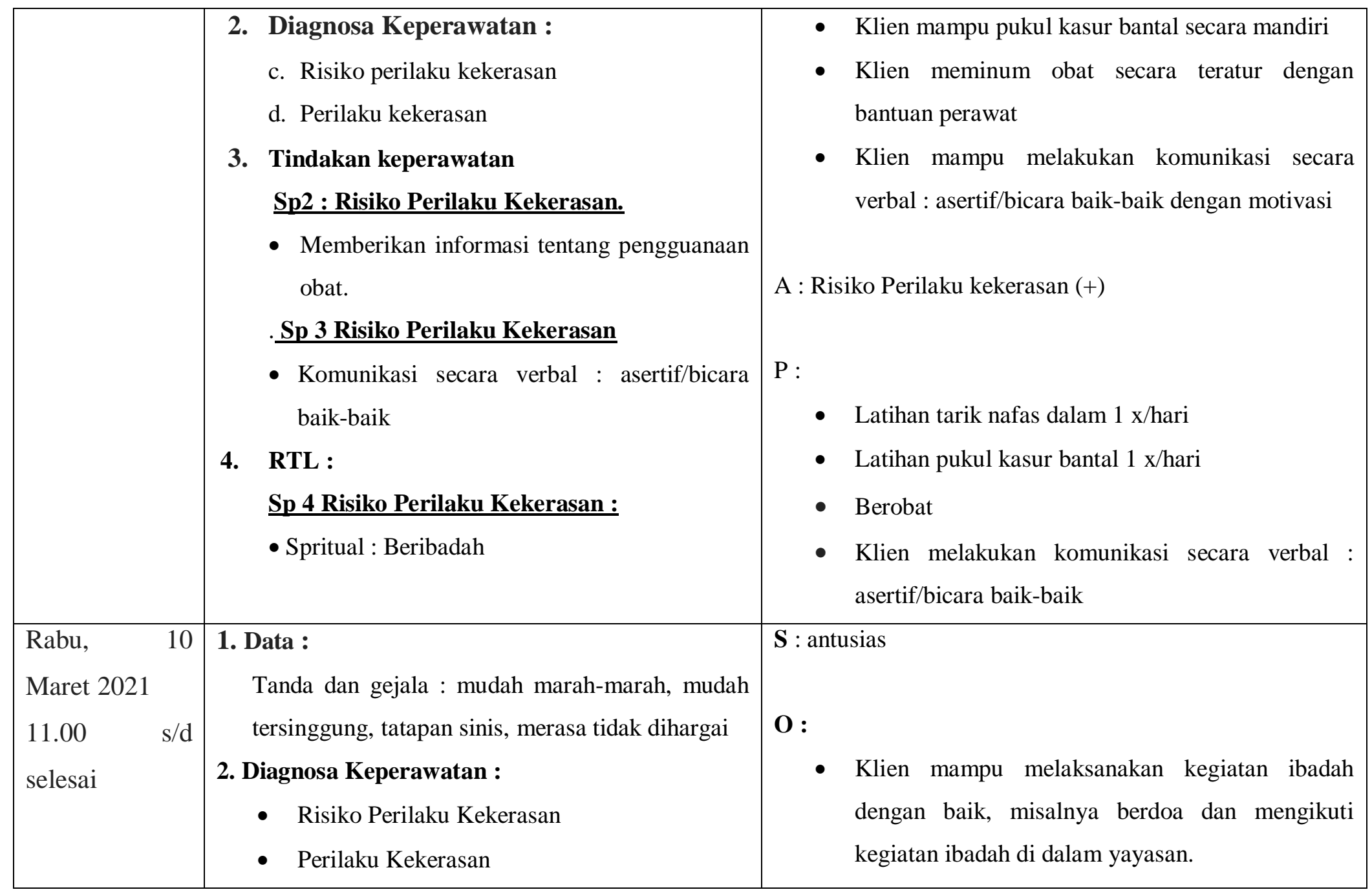




\begin{tabular}{|c|c|c|}
\hline & $\begin{array}{l}\text { 3. Tindakan keperawatan : } \\
\text { Sp } 4 \text { Risiko Perilaku Kekerasan } \\
\text { - } \begin{array}{l}\text { Mengevaluasi kemampuan klien dalam tarik } \\
\text { nafas dalam dan pukul kasur bantal, minum }\end{array} \\
\text { obat secara teratur dan bicara baik-baik. } \\
\text { - Melatih klien untuk melaksanakan kegiatan } \\
\text { spiritual yang sudah diatur. } \\
\text { 4. RTL : } \\
\text { - Risiko Perilaku Kekerasan : Follow up dan } \\
\text { evaluasi SP 1-4 risiko Perilaku Kekerasan }\end{array}$ & 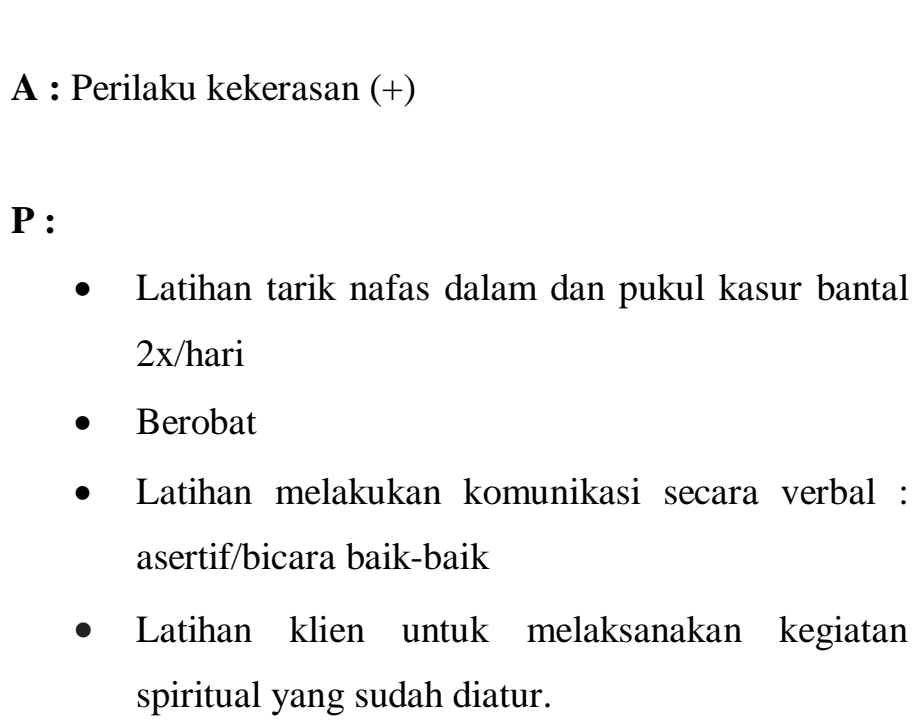 \\
\hline $\begin{array}{ll}\text { Jumat, } & 13 \\
\text { Maret } 2021 & \\
10.00 & \text { s/d } \\
\text { selesai } & \end{array}$ & $\begin{array}{l}\text { 1. Data } \\
\text { - Klien sering, mondar - mandir, berbicara } \\
\text { sendiri, berbicara ngawur, sering senyum- } \\
\text { senyum sendiri, sering mengarahkan } \\
\text { telinganya ke tempat - tempat tertentu. } \\
\text { - Klien sering mendengarkan suara - suara } \\
\text { tanpa wajah yang menyuruhnya untuk } \\
\text { berbicara bicara sendiri. } \\
\text { - Klien mengatakan suara - suara tersebut }\end{array}$ & $\begin{array}{l}\text { S : } \\
\text { Senang } \\
\text { O : } \\
\text { - Klien mampu mengenali halusinasinya dengan } \\
\text { mandiri } \\
\text { - Klien mampu menghardik halusinasinya dengan } \\
\\
\text { motivasi perawat. } \\
\text { A : Halusinasi pendengaran }(+)\end{array}$ \\
\hline
\end{tabular}




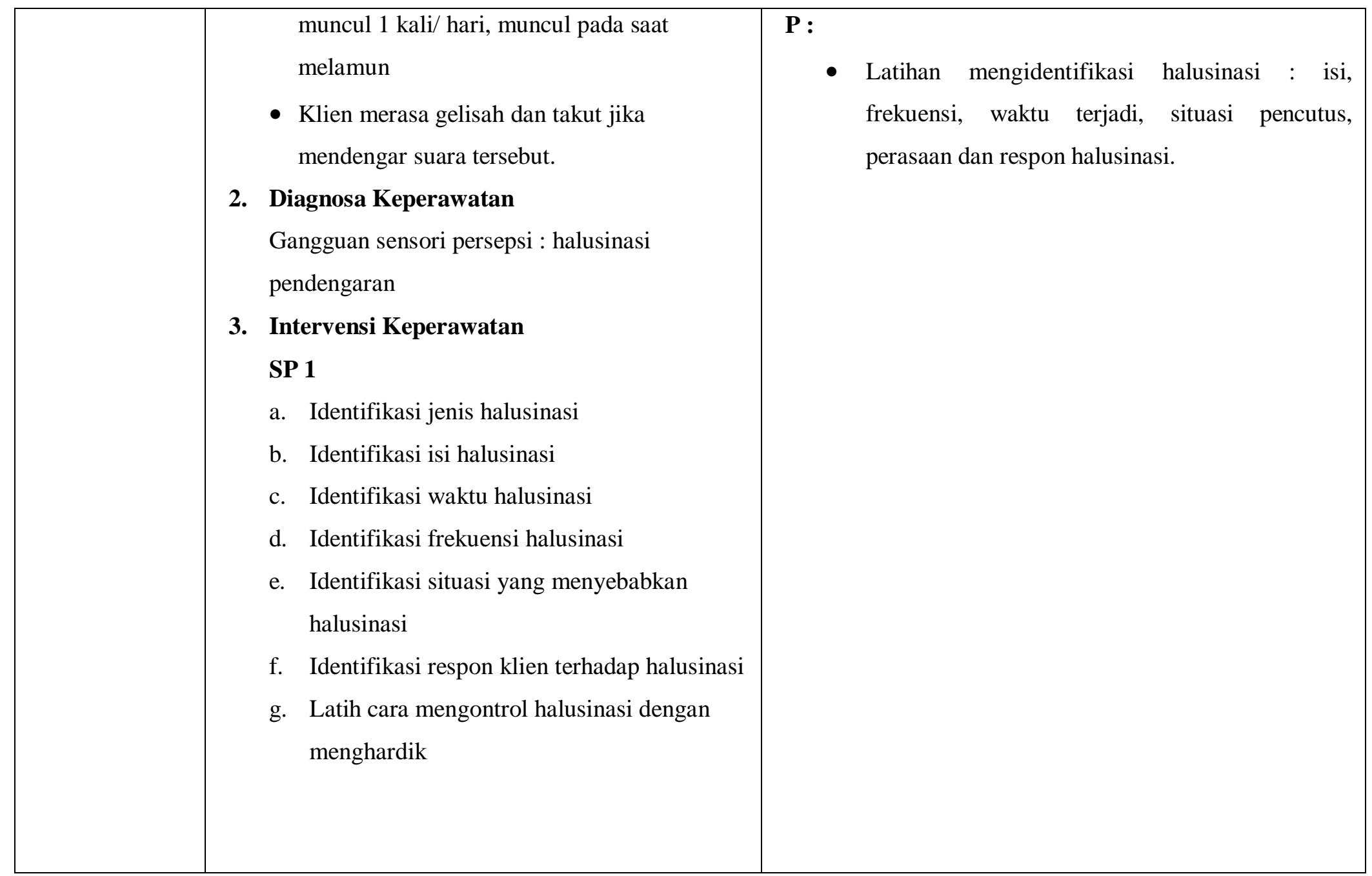




\begin{tabular}{|c|c|c|}
\hline & $\begin{array}{l}\text { 4. Implementasi Keperawatan } \\
\text { SP } 1 \text { : } \\
\text { a. Mengidentifikasi jenis halusinasi } \\
\text { b. Mengidentifikasi isi halusinasi } \\
\text { c. Mengidentifikasi waktu halusinasi } \\
\text { d. Mengidentifikasi frekuensi halusinasi } \\
\text { e. Mengidentifikasi situasi yang menyebabkan } \\
\text { f. Mengidentifikasi respon klien terhadap } \\
\text { halusinasi } \\
\text { g. Melatih cara mengontrol halusinasi dengan } \\
\text { menghardik } \\
\text { RTL } \\
\text { SP } 2 \text { (Latih cara minum obat secara teratur) }\end{array}$ & \\
\hline $\begin{array}{ll}\text { Selasa, } & 16 \\
\text { Maret } 2021 & \\
10.00 & \text { s/d } \\
\text { selesai } & \end{array}$ & $\begin{array}{l}\text { 1. Data } \\
\text { - Klien mengatakan mendengar suara-suara } \\
\text { tersebut namun sudah bisa mengendalikan } \\
\text { suara-suara tersebut dengan cara menghardik } \\
\text { dan bercakap-cakap dengan orang lain. } \\
\text { - } \text { Klien juga mau melakukan aktivitas sesuai }\end{array}$ & $\begin{array}{l}\text { S : } \\
\text { Klien senang dan antusias. } \\
\text { O: } \\
\text { Klien mampu mengontrol halusinasi dengan minum obat } \\
2 \text { kali dalam sehari. }\end{array}$ \\
\hline
\end{tabular}




\begin{tabular}{|c|c|c|}
\hline & $\begin{array}{l}\text { dengan jadwal yang sudah disusun } \\
\text { - Klien masih nampak berbicara sendiri } \\
\text { sesekali } \\
\text { 2. Diagnosa Keperawatan } \\
\text { Gangguan sensori persepsi : halusinasi } \\
\text { pendengaran } \\
\text { 3. Intervensi Keperawatan } \\
\text { SP } 2 \\
\text { Latih cara minum obat dengan prinsip } 6 \text { benar } \\
\text { 4. Implementasi Keperawatan } \\
\text { Melatih cara minum obat dengan prinsip } 6 \text { benar } \\
\text { 5. RTL : } \\
\text { SP } 3 \\
\text { (Mengendalikan halusinasi dengan bercakap-cakap } \\
\text { dengan orang lain) }\end{array}$ & $\begin{array}{l}\text { A : } \\
\text { Halusinasi pendengaran }(+) \\
\text { P : } \\
\text { - Latihan mengidentifikasi halusinasi : isi, frekuensi, } \\
\text { waktu terjadi, situasi pencetus, perasaan dan respon } \\
\text { halusinasi } \\
\text { - Latihan menghardik halusinasi } 3 \text { kali sehari } \\
\text { - Latihan minum obat dengan prinsip } 6 \text { benar } 2 \text { kali } \\
\text { sehari }\end{array}$ \\
\hline $\begin{array}{ll}\text { Jumat, } & 19 \\
\text { Maret } 2021 & \\
10.00 & \text { s/d } \\
\text { selesai } & \end{array}$ & $\begin{array}{l}\text { 1. Data } \\
\text { - Klien mengatakan mendengar suara - suara } \\
\text { yang isinya "Menyuruh klien memukul } \\
\text { orang yang disekitarnya" } \\
\text { - Klien mengatakan Suara-suara itu muncul }\end{array}$ & $\begin{array}{l}\text { S : } \\
\text { Klien dia merasa senang bisa bercakapcakap dengan } \\
\text { orang lain } \\
\text { O : } \\
\text { - Klien nampak sesekali berbicara sendiri dan }\end{array}$ \\
\hline
\end{tabular}




\begin{tabular}{|c|c|}
\hline $\begin{array}{l}\text { waktu pagi dan siang hari. } \\
\text { - } \text { Klien tampak bicara-bicara sendiri. Mulut } \\
\text { klien tampak komat-kamit. } \\
\text { 2. Diagnosa Keperawatan } \\
\text { Gangguan sensori persepsi : halusinasi } \\
\text { pendengaran } \\
\text { 3. Intervensi Keperawatan } \\
\text { SP } 3 \text { : } \\
\text { Latih mengendalikan halusinasi dengan bercakap } \\
\text {-cakap dengan orang lain } \\
\text { 4. Implementasi Keperawatan } \\
\text { SP } 3 \text { : } \\
\text { Melatih mengendalikan halusinasi dengan } \\
\text { bercakap-cakap dengan orang lain } \\
\text { 5. RTL } \\
\text { SP } 4 \text { (Mengendalikan halusinasi dengan } \\
\text { melakukan kegiatan yang biasa dilakukan di } \\
\text { yayasan) }\end{array}$ & $\begin{array}{l}\text { menutup kupingnya (menghardik halusinasi) } \\
\text { - Klien mempraktekkan cara bercakap-cakap dengan } \\
\text { orang lain } \\
\text { A : } \\
\text { Halusinasi pendengaran (+) } \\
\text { P : } \\
\text { - Latihan menghardik halusinasi } 3 \text { kali sehari } \\
\text { - Latihan minum obat dengan prinsip } 6 \text { benar } 2 \text { kali } \\
\text { - sehari } \\
\text { - Latihan bercakap-cakap dengan orang lain }\end{array}$ \\
\hline
\end{tabular}




\begin{tabular}{|c|c|c|}
\hline $\begin{array}{l}\text { Rabu, } \\
17 \text { Maret } 2021 \\
10.00 \quad \text { s/d } \\
\text { selesai }\end{array}$ & $\begin{array}{l}\text { 1. Data } \\
\text { - Klien mengatakan masih mendengar suara- } \\
\text { suara tersebut namun sudah bisa } \\
\text { mengendalikan suara-suara tersebut dengan } \\
\text { cara menghardik dan bercakap-cakap dengan } \\
\text { orang lain. } \\
\text { - Klien mengatakan mau melamun karena } \\
\text { tidak ada kegiatan. } \\
\text { - Klien tampak bicara-bicara sendiri. Mulut } \\
\text { klien tampak komat-kamit. } \\
\text { 2. Diagnosa Keperawatan } \\
\text { Gangguan sensori persepsi : halusinasi } \\
\text { pendengaran } \\
\text { 3. Intervensi Keperawatan } \\
\text { SP } 4 \\
\text { Latih mengendalikan halusinasi dengan } \\
\text { melakukan kegiatan yang biasa dilakukan di } \\
\text { yayasan }\end{array}$ & $\begin{array}{l}\text { S : } \\
\text { Semangat dan antusias } \\
\text { - } \\
\text { Alien mampu melakukan kegiatan yang biasa } \\
\text { dilakukannya di Yayasan dan kegiatan tersebut } \\
\text { A : Halusinasi pendengaran (+) } \\
\text { P : } \\
\text { - Latihan menghardik halusinasi } 3 \text { kali sehari } \\
\text { - Latihan minum obat dengan prinsip } 6 \text { benar } 2 \text { kali } \\
\text { - } \quad \text { Lehari } \\
\text { - } \quad \text { Meharihan bercakap-cakap dengan orang lain } 3 \text { kali } \\
\text { Melakukan aktivitas terjadwal setiap hari }\end{array}$ \\
\hline
\end{tabular}


4. Implementasi Keperawatan

Melatih mengendalikan halusinasi dengan

melakukan kegiatan yang biasa dilakukan di

rumah sakit

5. RTL

Follow up dan Evaluasi SP 1 - SP 4 Halusinasi 


\section{BAB 4 \\ PEMBAHASAN}

Setelah penulis melaksanakan asuhan keperawatan kepada Tn. A dengan Risiko Perilaku Kekerasan/Perilaku Kekerasan di Yayasan Pemenang Jiwa Sumatera, maka mahasiswa pada $\mathrm{BAB}$ ini akan membahas kesenjangan antara teoritis dan tinjauan kasus. Pembahasan dimulai melalui tahapan proses keperawatan yaitu pengkajian, diagnosa keperawatan, perencanaan, pelaksanaan dan evaluasi.

\subsection{Tahap Pengkajian}

Selama pengkajian dilakukan pengumpulan data dari beberapa sumber yaitu dari klien dan pengawas yayasan. Mahasiswa mendapat sedikit kesulitan dalam mmenyimpulkan data kerena keluarga klien jarang mengunjungi klien di yayasan pemenang jiwa. Maka mahasiwa melakukan pendekatan pada klien melalui komunikasi terapeutik yang lebih terbuka membantu klien untuk memecahkan perasaannya dan juga melakukan observasi kepada klien. Ada pun upaya tersebut yaitu :

1. Melakukan pendekatan dan membina hubungan saling percaya diri pada klien agar klien lebih terbuka dan lebih percaya dengan menggunakan perasaan.

2. Mengadakan pengkajian klien dengan wawancara dan tidak menemukan kesenjangan karena di temukan hal sama seperti diteori bahwasanya Perilaku kekerasan merupakan respon maladaptif dari kemarahan, hasil dari kemarahan yang ekstrim ataupun panik. Perilaku kekerasan yang timbul pada klien skizofrenia diawali dengan adanya perasaan tidak berharga, takut,dan ditolak oleh lingkungan sehingga individu akan menyingkir dari hubungan interpersonal dengan oran lain (Pardede, Keliat \& Yulia, 2015).

\subsection{Tahap Perencanaan}

Perencanaan dalam proses keperawatan lebih dikenal dengan rencana asuhan keperawatan yang merupakan tahap selanjutnya setelah pangkajian dan penentuan diagnosa keperawatan. Pada tahap perencanaan penulis hanya menyusun rencana tindakan keperawatan sesuai dengan pohon 
masalah keperawatan yaitu :perilaku kekerasan. Pada tahap ini antara tinjauan teoritis dan tinjaun kasus tidak ada kesenjangan sehingga penulis dapat melaksanakan tindakan seoptimal mungkin dan didukung dengan seringnya bimbingan dengan pembimbing.

Secara teoritis digunakan cara strategi pertemuan sesuai dengan diagnosa keperawatan yang muncul saat pengkajian. Adapun upaya yang dilakukan penulis yaitu :

1. Risiko Perilaku Kekerasan

a. Mengidentifikasi isi Risiko Perilaku Kekerasan

b. Mengidentifikasi waktu terjadi Risiko Perilaku Kekerasan

c. Mengidentifikasi situasi pencetus Risiko Perilaku Kekerasan

d. Mengidentifikasi respon terhadap Risiko Perilaku Kekerasan

e. Membantu klien mempraktekan latihan cara mengontrol Risiko Perilaku Kekerasan dengan tarik napas dalam dan pukul kasur bantal

f. Menjelaskan cara mengontrol perilaku kekerasan dengan minum obat

g. Melatih klien mengontrol Risiko Perilaku Kekerasandengan berbicara baik-baik dengan orang lain dan spritual

h. Mengevaluasi jadwal kegiatan harian klien

2. Gangguan Persepsi Sensori Halusinasi Pendengaran

a. Mengajarkan klien mengidentifikasi isi, waktu terjadi, situasi pencetus, dan respon terhadap halusinasi

b. Melatih klien teknik menghardik

c. Melatih klien mengontrol alusinasi dengan minum obat secara teratur

d. Mengajarkan klien cara mengontrol halusinasi dengan bercakap cakap dengan orang lain

e. Mengajarkan cara mengontrol halusinasi dengan melakukan kegiatan terjadwal 


\subsection{Tahap Implementasi}

Pada tahap implementasi mahasiswa hanya mengatasi satu masalah keperawatan dengan diagnosa keperawatan Risiko perilaku Kekerasan/Perilaku Kekerasan karena masalah utama yang dialami klien. Pada diagnosa keperawatan Risiko Perilaku Kekerasan/Perilaku Kekerasan strategi pertemuan ialah mengidentifikasi perilaku kekerasan, mengotrol perilaku kekerasan, dan cara tarik nafas dalam dan pukul bantal kasur. Strategi pertemuan yang kedua ialah anjurkan minum obat secara teratur, strategi pertemuan ketiga ialah latihan cara komunikasi secara verbal atau bicara baik-baik dan strategi terakhir pertemuan keempat yaitu spritual.

\subsection{Tahap Evaluasi}

Pada tinjauan kasus evaluasi yang dihasilkan adalah :

1. Klien sudah dapat mengontrol dan mengidentifikasi Risiko Perilaku Kekerasan

2. Klien dapat mengendalikan Risiko Perilaku Kekerasan melalui latihan fisik

3. Klien dapat mengendalikan Risiko Perilaku Kekerasan dengan cara pergi ke poli jiwa untuk mendapatkan minum obat

4. Klien dapat mengendalikan Risiko Perilaku Kekerasan dengan berbicara baik-baik dengan orang lain

5. Klien dapat mengendalikan Risiko Perilaku Kekerasan dengan melakukan spritual terjadwal. 


\section{BAB 5 \\ PENUTUP}

\subsection{Kesimpulan}

Setelah menguraikan tentang proses keperawatan pada Tn. A penulis melanjutkan asuhan keperawatan pada klien dengan risiko perilaku kekerasan di Yaysan Pemenang Jiwa. Maka penulis mengambil kesimpulan untuk meningkatkan mutu asuhan keperawatan yang telah ada :

1. Dalam melakukan asuhan keperawatan pada klien dengan kasus perilaku kekerasan dilakukan meliputi aspek psikososial, spiritual dan melibatkan keluarga didalamnya.

2. Dalam melakukan asuhan keperawatan maka antar perawat dan klien harus membina hubungan saling percaya.

3. Bagi mahasiswa/mahasiswi agar lebih memperdalam ilmu pengetahuan khususnya tentang keperawatan jiwa.

4. Bagi klien agar dapat berkomunikasi dan berinteraksi dengan baik serta klien mengikuti pengobatan secara optimal sampai berhasil agar tidak terulang kembali.

5. Peran serta keluarga sangat penting dalam penyembuhan klien karena dengan dukungan keluarga penyembuhan klien dapat tercapai sesuai dengan yang diharapkan.

\subsection{Saran}

1. Diharapkan pada keluarga sering mengunjungi klien selama waktu perawatan karena dengan seringnya keluarga berkunjung, maka klien merasa berarti dan dibutuhkan dan juga setelah pulang keluarga harus memperhatikan obat dikonsumsi serta membawa klien kontrol secara teratur kepelayanan kesehatan jiwa ataupun rumah sakit jiwa.

2. Bagi mahasiswa/mahasiwi agar lebih memperdalam ilmu pengetahuan khusus tentang keperawatan jiwa. 


\section{DAFTAR PUSTAKA}

Arisandy, W., \& Juniarti, A. (2020). Penerapan Strategi Pelaksana Pada Asuhan Keperawatan Pasien Dengan Risiko Perilaku Kekerasan. Babul Ilmi Jurnal Ilmiah Multi Science Kesehatan, 12(2). http://jurnal.stikes-aisyiyahpalembang.ac.id/index.php/Kep/article/view/514

Aziz, N. R. (2018). Pengaruh Terapi De-Eskalasi Terhadap Perubahan Perilaku Pasien Dengan Risiko Perilaku Kekerasan Di RDSJD Atma Husada Mahakam Samarinda. Skripsi. Program Studi D-IV Keperawatan Politeknik Kesehatan Kalimantan Timur

Bengi, N. S. (2021). Penerapan Asuhan Keperawatan Jiwa Pada Tn. A Dengan Risiko Perilaku Kekerasan. 10.31219/osf.io/bmraq

Dwi P, F., \& Arum P, S. K. (2017). Mekanisme Koping Pada Pasien Perilaku Kekerasan Dengan Risiko Menciderai Orang Lain Dan Lingkungan (Doctoral dissertation, Universitas Muhammadiyah Surakarta). http://eprints.ums.ac.id/52420/

Fhadilah, N. C., Adi, W. S., \& Shobirun, S. (2017, August). Pengaruh Terapi Relaksasi Otot Progresif Terhadap Pasien Risiko Perilaku Kekerasan di RSJD dr Amino Gondohutomo Provinsi Jawa Tengah. In Jurnal Forum Kesehatan (Vol. 7, No. 2, pp. 83-89). http://e-journal.poltekkespalangkaraya.ac.id/jfk/article/view/90

Hasannah, S. U. (2019). Asuhan Keperawatan Jiwa pada Pasien Dengan Risiko Perilaku Kekerasan (Doctoral dissertation, STIKes Kusuma Husada Surakarta). http://eprints.ukh.ac.id/id/eprint/41

Hulu, R. K. (2021). Asuhan Keperawatan Jiwa Pada Tn. A Dengan Risiko Perilaku Kekerasan Di Yayasan Pemenang Jiwa Sumatera. 10.31219/Osf.Io/Gnyxe

Kandar, K., \& Iswanti, D. I. (2019). Faktor Predisposisi dan Prestipitasi Pasien Risiko Perilaku Kekerasan. Jurnal Ilmu Keperawatan Jiwa, 2(3), 149- 156. http://dx.doi.org/10.32584/jikj.v2i3.226

Kemenkes RI. (2019). Riset Kesehatan Dasar, RISKESDAS. Jakarta : Kemenkes RI. https://databoks.katadata.co.id/datapublish/2019/10/08/persebaranprevalensi-skizofreniapsikosis-di-indonesia

Malfasari, E., Febtrina, R., Maulinda, D., \& Amimi, R. (2020). Analisis Tanda dan Gejala Risiko Perilaku Kekerasan pada Pasien Skizofrenia. Jurnal Ilmu Keperawatan Jiwa, 3(1), 65-74. https://journal.ppnijateng.org/index.php/jikj/article/view/478

Nurhalimah. (2016). Bahan Ajar Keperawatan Jiwa. Jakarta 
Pardede, J. A. (2020). Standar Asuhan Keperawatan Jiwa Dengan Masalah Risiko Perilaku Kekerasan. 10.31219/osf.io/we7zm

Pardede, J. A., Simanjuntak, G. V., \& Laia, R. (2020). Gejala Risiko Perilaku Kekerasan Menurun Setelah Diberikan Prgressive Muscle Relaxation Therapy Pada Pasien Skizofrenia. 3 (2). 91-100. http://dx.doi.org/10.32584/jikj.v3i2.534

Pardede, J. A., Siregar, L. M., \& Hulu, E. P. (2020). Efektivitas Behaviour Therapy Terhadap Risiko Perilaku Kekerasan Pada Pasien Skizofrenia Di Rumah Sakit Jiwa Prof. Dr. Muhammad Ildrem Provsu Medan. Jurnal Mutiara Ners, 3(1), 8-14. http://114.7.97.221/index.php/NERS/article/view/1005

Prasetya, A. S. (2018). Penerapan Terapi Musik Pada Pasien Yang Mengalami Risiko Perilaku Kekerasan Di Ruang Melati Rumah Sakit Jiwa Provinsi Lampung. Jurnal Kesehatan Panca Bhakti Lampung, 6(1), 84-90. http://ejournal.pancabhakti.ac.id/index.php/jkpbl/article/view/23

Prasetya, A. S. (2018). Efektifitas Jadual Aktivitas Sehari-Hari Terhadap Kemampuan Mengontrol Perilaku Kekerasan. Jurnal Kesehatan Panca Bhakti Lampung, 6(1), 18-29. http://ejournal.pancabhakti.ac.id/index.php/jkpbl/article/view/22

Putri, V. S., \& Fitrianti, S. (2018). Pengaruh Strategi Pelaksanaan Komunikasi Terapeutik Terhadap Risiko Perilaku Kekerasan Pada Pasien Gangguan Jiwa Di Rumah Sakit Jiwa Provinsi Jambi. Jurnal Akademika Baiturrahim Jambi, 7(2), 138-147. http://dx.doi.org/10.36565/jab.v7i2.77

Sujarwo, S., \& Livana, P. H. (2019). Studi Fenomenologi: Strategi Pelaksanaan Yang Efektif Untuk Mengontrol Perilaku Kekerasan Menurut Pasien Di Ruang Rawat Inap Laki Laki. Jurnal Keperawatan Jiwa, 6(1), 29-35. https://doi.org/10.26714/jkj.6.1.2018.29-35

Suryanti, S., \& Ariani, D. (2018). Pengaruh Relaksasi Progresif Terhadap Penurunan Perilaku Kekerasan Pada Pasien Skizofrenia Di Rumah Sakit Jiwa Daerah Klaten. Interest: Jurnal Ilmu Kesehatan, 7(1), 67-74. https://doi.org/10.37341/interest.v7i1.74

Untari, S. N. (2021). Asuhan keperawatan jiwa pada pasien dengan risiko perilaku kekerasan (Doctoral dissertation, Perpustakaan Universitas Kusuma Husada Surakarta). http://eprints.ukh.ac.id/id/eprint/961/

Utari, D. (2021). Asuhan Keperawatan Jiwa Pada Ny. H Dengan Risiko Perilaku Kekerasan Di Desa Juli Seutuy Bireuen. 10.31219/osf.io/jhg52 
Wulansari, E. M. \& Sholihah, M, M. (2021). Asuhan Keperawatan Jiwa Pada Pasien Dengan Risiko Perilaku Kekerasan Dirumah Sakit Daerah Dr Arif Zainuddin Surakarta (Doctoral dissertation, Universitas Kusuma Husada Surakarta). http://eprints.ukh.ac.id/id/eprint/1020 